\title{
Communication on Road Safety in Cameroon: Representation in the Press and Government Strategy
}

\section{Corine Esse}

Department of Corporate Communication-Advanced School of Mass Communication (ASMAC), University of Yaounde II, Yaounde, Cameroon

Email: princessecorine820@gmail.com

How to cite this paper: Esse, C. (2021) Communication on Road Safety in Cameroon: Representation in the Press and Government Strategy. Int. J. Communications, Network and System Sciences, 14, 55-73. https://doi.org/10.4236/ijcns.2021.145005

Received: April 30, 2021

Accepted: May 28, 2021

Published: May 31, 2021

Copyright ( 2021 by author(s) and Scientific Research Publishing Inc. This work is licensed under the Creative Commons Attribution International License (CC BY 4.0).

http://creativecommons.org/licenses/by/4.0/ (c) (i) Open Access

\begin{abstract}
Road safety is a major concern in Cameroon, due to the multiplicity of road accidents resulting in the loss of human lives and the deterioration of road infrastructures. In 2019, the year marking the end of the United Nations decade of actions for road safety, the number of deaths on Cameroonian roads was 937 . In this article, we have selected to examine the theme of road safety in the Cameroonian press and to look at awareness-raising strategies on the same subject. Our objective is to highlight the importance of communication in solving road safety problems. We therefore asked ourselves the following questions: How is the topic of road safety dealt with in the media? In combination with awareness campaigns, are the representations conveyed through the press sufficient to contribute to a change in road users behaviour? The option of studying both the representations of road safety that we have chosen has enabled us to show how the co-production of this public problem can be explained through the interrelations between the media and institutional fields. We initially postulated that communication achieves its objective in road safety campaigns when it integrates mixed strategies including campaigns aimed at road users, information for the general public through the press and social marketing campaigns aimed at changing behaviour. After a content analysis of articles published on road safety in three newspapers and an analysis of the messages disseminated in the posters and flyers produced during awareness campaigns, we found that awareness-raising through the media is not enough on its own. We therefore conclude that it is important to combine marketing techniques, citizen education and awareness raising aimed at changing user behaviour in road safety communication strategies. The target strategy is also important because each road safety message is addressed to a specific target group that plays a specific role.
\end{abstract}




\section{Keywords}

Social Communication, Road Safety, Communication for Development

\section{Introduction}

Road safety in this study represents the set of norms, mechanisms and measures taken by the different actors in charge of road infrastructure construction and road traffic management in order to ensure the protection of road users and their property [1]. It is one of the major concerns in Cameroon, due to the multiplicity of road accidents resulting in numerous losses of human life and property and the deterioration of road infrastructure. It can be considered as the search for an ideal that goes through several axes targeting the state of vehicles, the quality of road infrastructure and the behaviour of road users. In 2019, the year marking the end of the United Nations decade of action for road safety, the number of deaths on Cameroonian roads was 937, while it was 1588 in 2011. According to the ministry in charge of transport, this decrease is justified by the strengthening of technical inspection procedures, the intensification of road prevention and the compliance of road signs. This study examines the effectiveness of communication in road safety awareness strategies. It highlights the way in which the Cameroonian press deals with the theme of road safety while looking at the public authorities' awareness strategies on the same subject. It comes at a time when road accidents are on the increase, despite the government's awareness-raising measures, and at a time when several road and highway infrastructures are being built. Indeed, the resurgence of road accidents, the resulting deaths and the fact that the road remains the primary means of moving people and goods have led the public authorities to address the problem of road safety. In order to be in line with the country's development objectives, actions are being taken to reduce road accidents and preserve the road heritage.

Part of the following questions: How is the topic of road safety addressed in the media? In combination with awareness campaigns, are the representations conveyed through the press sufficient to contribute to a change in road users behavior? We assume that in the implementation of campaigns, road safety communication and media coverage tend to be developed with the aim of reaching specific audiences and taking into account more localised practices.

With regard to previous research on the subject of road safety, it should be noted that very few researchers have focused on the information and communication aspects of road safety. While there are several works that deal with road safety, very few deal with road safety communication. In a doctoral thesis entitled "Beliefs and safety behaviors of road users and agents: a study of perceptions and naive explanations of road accidents in Cameroon", defended in 2012, Nguetsa [2] attempts to identify the behaviors of Cameroonians on the roads. Starting from the naive explanations of accidents and the perception of risk that 
affect the behaviour of road users and agents in Cameroon, he examines 522 real accident reports and shows that a large majority of accidents occur in good driving conditions. It states that in a road accident situation, drivers blame each other, but agree with the gendarmes that driver behavior is the primary cause of road accidents in Cameroon.

In a research entitled "The challenges of road safety in urban areas in Cameroon: the case of motorbike taxis in Yaoundé", Djiepmo Ndjoukya [3] interested to the problem of motorbike taxi transport, which has become part of the population's customs, and its relationship with road safety (2008). With the aim of seeking perspectives for improving road safety in the motorbike taxi activity in Cameroon, the author notes that in 2006 alone, just over 600 cases of motorbike taxi accidents were recorded at the Yaoundé University Hospital, including 150 deaths, i.e. $25 \%$ of those involved. He concluded by developing a multi-level road safety system. In a Master's thesis entitled "Effectiveness of road prevention measures on the behaviour of road users in Cameroon", Hadji [4] questioned the behaviour of road users and the effectiveness of road prevention measures. He believes that road prevention measures need to be studied in depth in order to influence the behaviour of road users (motorists, motorcyclists, pedestrians) in Cameroon in a favorable way and specifies that, in general, in the context of road safety, strategies for influencing so-called social behaviors aim to encourage individuals to adopt a new behaviour and to give up engaging in a behaviour that is considered harmful or dangerous. However, we can say that the present research is of great interest because it tackles an issue that has been little explored. Indeed, previous research has focused more on the road, vehicles and accidents, without really emphasising the communication strategies that should contribute to facilitating behavioral change among road users. Therefore, the objectives we wish to achieve through this study are the following:

- Assess the way in which the topic of road safety is treated in the press;

- Identify the strategic axes of media coverage of road safety issues;

- To determine the place of communication in road safety awareness campaigns;

- Evaluate the effectiveness of the chosen lines of communication in road safety campaigns and assess the place of the target.

\section{Behavior Change Communication at the Heart of Our Theoretical Positioning}

Behavior change communication is an approach to development communication that has become very common in the field of public action. It is part of the field of social communication and can be used to understand the communicative activity around road safety campaigns. Our theoretical position puts forward the impact of communication for social change in the field of road safety. According to Misse Misse [5], communication for social change refers to the cognitive level, to the works intended to grasp the readability of practices and knowledge devices instituted in the field of social changes, as well as the modalities of their con- 
stitution by social communication.

On the strategic level, communication for social change is an institutionalized set of mediation practices. It constitutes at the same time a device of influence and a product of relations of power between various groups of social actors who aim at the same time at a concrete objective of strategic profitability. Lerner [6], on his part, builds his paradigm from the theory of modernization. His institutional approach places the multiplier and amplifying effects of the mass media in the center of the processes which accelerate the social transformations. Lerner considers the systems of communication as markers of borders between two types of social formations: the "modern" society in which the systems of the media teach the new knowledge, attitudes and behaviors on the one hand and the "traditional" society marked by the oral communication on the other hand. For him, the passage from the model of oral communication to the mass communication would mark the entry of a social formation in the phase of its modernization: the modernization is transmitted today by means of mass information. These chain reactions lead, according to Lerner, to a wider participation of the populations in the economic and political activities.

The problem therefore revolves around the question of how to influence road users and even citizens in order to bring about positive changes in road safety. It is therefore necessary to recognize the role of information as the apparently necessary starting point for any communication and/or strategic action in favour of road communication. Information delivered by road safety communication campaigns and messages is intended to positively affect intention, attitudes, subjective norms and self-efficacy, i.e., what influences the user's behavior.

Communication for social change therefore requires a relationship of partnership and reciprocity that allows messages to be adapted to reality. The contents, forms, methods and means of communication must correspond to the needs, aspirations and value systems of development actors. It is therefore necessary to consider a model of convergence seen as a process by which the actors build a reality by and through the sharing of information, in order to achieve mutual understanding. The focus is therefore on information that is "shared" equitably between actors in a relationship of symmetry.

As soon as the negative behavior identified is attributable to a lack or deficit of information, providing information amounts to correcting the behavior in the desired direction. Ultimately, it can be argued that risky behavior (e.g., violating traffic signals, speeding) is and remains the clear expression of a lack of information. At best, negative behavior is an expression of habits formed through repeated practices, which are likely to change through the repetition and retention of positive messages. As soon as there is contact between the transmission media and the targets, the negative behaviour should gradually fade away. This is the epistemological, theoretical and strategic framework within which information, education and communication (IEC)/behavior change communication (BCC) materials are produced and developed, disseminated and evaluated. For effective communication, it is therefore important to integrate parameters related to the 
social perceptions, attitudes, and cultural practices of the target audiences. This successful communication contributes to the production of a preventive discourse on risk, and determines the conditions for its creativity. The process is also one of producing symbolic goods. The basic principle is that the construction of messages must be guided by analysis (research) and strategic design. But, messages must also have an emotional and artistic potential capable of influencing the target audiences. The search for effectiveness justifies that, in the process of making road safety discourse, messages are systematically pre-tested and later regularly evaluated. This conception of appropriate communication determines the issues of its own reception. All actions (campaigns and/or development of messages and IEC materials) should be pre-tested at various points in the process. Pre-testing is seen as an important step to see what works, what may be misunderstood, and to ensure that the content is clear and effective. It is about checking the value of the message against a number of criteria that can be used to verify and justify whether a communication is "good" or "bad", whether it "gets through" or "doesn't".

As far as awareness-raising is concerned, is not the same thing as making people change; raising awareness means drawing their attention, under the influence of the media, to an issue or to the subject of a debate. The information disseminated on a road safety problem provides demographic, sociological and psychological data that can influence people's perception of the problem and thus raise their awareness of the issue. As noted above, information would affect attitudes, subjective norms and self-efficacy expectations, i.e. the very components of behavioral intention in the revised theory of reasoned action, which has been transformed into a theory of planned action. It is essential that road safety actions attempt to change people's behaviour. However, it should be noted that the real problem of communication interventions for behaviour change is the effectiveness of the communicative action, the decision-making process, the transition from the intention to act to the actual action. Research in the field of road safety has attempted to isolate certain elements likely to place the driving or behavioral system in a situation of failure (Bernier and Dumond) [7]. The literature generally tends to view road crashes as a multifactorial problem, with human, vehicle and environmental factors being the main ones identified by these studies (Shinar) [8]. Other research (Higelé and Hernja) [9] orients road accidents of novice drivers to the characteristics of youth. Based on this observation, it is felt that road safety measures must be studied in depth in order to influence the behavior of road users in Cameroon in a favorable manner. Hence the interest in studying road safety through the prism of behavior change communication. Generally speaking, in the context of road safety, strategies for influencing so-called social behaviors aim to encourage individuals to adopt a new behavior (systematic use of seat belts), to refrain from engaging in a behavior considered harmful or dangerous (preventive action; not consuming alcohol before driving) and/or to modify or abandon an existing behavior (excessive speed) (Andreasen; Kotler and Roberto) [10] [11]. 


\section{Methodological Approach}

From a methodological point of view, we chose to analyse the content of articles on road safety in the press, particularly in the titles "Mutations", "Le Messager" and "Cameroon tribune" on the one hand, and on the other hand to analyse some of the products of awareness campaigns on the roads, such as posters, flyers and messages published in the press. Our corpus is made up of 60 articles on the issue of road safety published in 2018, 2019 and 2020. In order to build up this corpus, we analysed all the articles published by these newspapers during the years under study. According to Berelson (Cité par Bonville) [12], "content analysis is a research technic for the objective, systematic and quantitative description of the manifest content of communications" [12]. In other words, content analysis makes it possible to trace, quantify and even evaluate the ideas or subjects present in a set of documents: the corpus. The method of analysis that we are highlighting in this study aims to discern and grasp the meaning and impact of the information transmitted by the media through press articles, by examining both their quantity and quality. It is therefore a question of analysing press articles by tracing what they have said, and then evaluating their content according to a specific problem. The key element of our method is the unit of information, a unit of meaning and measurement, which represents an idea or a topic and which is evaluated by the coder. It can be a word, a sentence or one or more paragraphs. It is the compilation of these units that measures the frequency and orientation of the media. The press disseminates content that is generally neutral and objective. However, both in the type of news it chooses to report and in the way it does so, it is inevitably biased because it takes a position. Content analysis therefore appeared to us to be the appropriate method for detecting the exact meaning of published information on road safety.

When we try to analyse the forms of conceptualisation of road safety in the press article, the polysemy of the term "safety" reveals two trends. The first is related to the responsibility of the state towards road users, and the second is characterised by an indexation of the users who are the managers of transport agencies. The written press appears to be an important channel for transmitting information on road safety and therefore plays a key role in understanding everything that revolves around this issue. With regard to the written press in particular, it should be noted that the theme of road safety has been imposed on the media agenda as both an emergency and a subject worthy of being covered by the media, due to the resurgence of traffic accidents. Therefore, what type of discourse is conveyed and/or constructed by actors such as the media, in this case the print media, with regard to the role played by the latter?

The analysis of press article on road safety produced during our study period is of definite interest. Indeed, since the 1990s, we have been dealing with a press of opinion that has made the critical examination of government actions its hobbyhorse (Nga Ndongo) [13]. We have selected three media outlets: "Cameroon Tribune", "Mutations" and "Le Messager". This is justified by the fact that 
they are three dailies widely distributed in Cameroon and of different political orientations, which can be considered representative of the Cameroonian daily press.

"Cameroon Tribune" was founded in 1974. It is a state-owned newspaper considered to be pro-government. It reports facts related to national, regional and foreign news. The articles are divided into the following topics, in a context of road network development, is built on a dominant vision of the problem that associates road insecurity, with a problem of deviant behavior, handled by the control of the forces of law and order, other institutions and civil society, involved in the fight for road safety. "Le Messager" is a daily newspaper created in 1979 and considered the main opposition newspaper in Cameroon. There are also several sections in this daily. These include the following sections "General news", linked to political news, social events; a regional section whose name varies according to the region of interest to the newspaper ("La Côtière" for news from the city of Douala, "le Septentrion" for news from the Northern regions); "Announcements"; "Sports"; "International". The articles are published in French and the editorial policy is, beyond classical communication, to point out and criticize the inadequacies of the views and actions of the government in place. The daily "Mutations" was created in July 1996. It focuses on national and international news and includes the following sections: "Politics"; "Institutional"; "Message" for advertisements and announcements; "Vivre aujourd'hui"; "Symbioses", a science, health and environment supplement; "Sports"; "Avenir", an Education, Training, Employment and Youth supplement; "Culture"; "International"; "Markets", which focuses on market fluctuations, prices of basic products, etc.; and the "Economy" section. However, it should be noted that these sections are not stable and do not appear in all editions.

\section{Road Safety and Infrastructure}

Road safety in Cameroon, as in many countries, involves many institutional actors, including the Ministry of Transport, other government agencies, the private sector, and non-governmental organizations. The analysis of road safety trends over the last decade was carried out from two angles: the evolution of some general data on road transport in Cameroon and the road safety indicators with the evolution of accident rates. Average daily road traffic varies from 11,000 to over 7000 vehicles, with an average of 743 vehicles per day for all roads and 1700 vehicles per day for paved roads. Cameroon's road network is approximately 112,973 kilometers, with a total of 10,158 kilometers of paved roads and 102,815 kilometers of dirt roads. The paved roads include 5633 kilometers of interurban roads and 4525 kilometers of urban roads. Except for national roads, 57 percent of which are paved, although some are in an advanced state of deterioration, most interurban roads are still in bad condition. The proportion of paved roads, excluding urban roads, is only 06 percent of the overall road network. The most heavily used roads are: Douala-Yaoundé, Douala-Bafoussam, Yaoundé-Bafoussam, Douala-Limbe, Bafoussam-Bamenda and Bafoussam-Dschang. 
Overall, Cameroon recorded a total of 116,081 accidents over the 2008-2014 period, averaging 16,583 accidents per year (nearly 46 accidents per day). To these sad records, the month of August 2017 still stood out with 98 deaths from traffic accidents on national roads (Cameroon tribune) [14]. The vast majority of these accidents (81.25 percent) occurred in urban areas, compared to 18.75 percent in interurban areas. The total number of accident decreased by $44 \%$ between 2008 and 2014, a decrease that was primarily due to the 50\% reduction in urban accident that occurred between 2013 and 2014. Compared to the situation before 2009, the number of material accident recorded by the National Gendarmerie force (interurban roads) decreased by $20 \%$, while at the same time the number recorded by the National Police force (urban roads) increased by $13 \%$. The number of body injury accident decreased by $23 \%$ according to the National Gendarmerie force and by $47 \%$ according to the National Police force. The number of recorded fatal accident increased by $6 \%$ and $160 \%$ for interurban and urban areas respectively. The distribution of urban accidents according to their typology highlights the fact that material accident account for almost $70 \%$ of the total, while injury and fatal accidents account for about $25 \%$ and $5 \%$ respectively.

During the period 2008-2014, 3.64\% of accidents were related to environmental factors, $15.39 \%$ to mechanical factors (related to the poor condition of vehicles) and $80.97 \%$ to human factors. Three major human factors alone are responsible for nearly $70 \%$ of the accidents recorded, including: driver inattention and distraction (30.67\%), over speeding (19.97\%) and lack of driver control (18.53\%). These were followed by: pedestrians (human factors): $3.60 \%$; unsafe passing: $3.15 \%$; defective tires: $2.80 \%$; unsafe man overs on the roadway: $2.34 \%$; and poor road conditions: $2.20 \%$. The causes of accident related to driver inattention and distraction, as well as those related to driver lack of control, are often associated with drinking and driving. Estimates made in the context of the study for the elaboration of the National Strategy for Road Safety and Prevention (2009) put the economic losses suffered by Cameroon due to road accidents at nearly 100 billion CFA francs per year, equivalent to 1 percent of the gross domestic product for that period.

\section{Causes of Road Insecurity}

With regard to the causes of road accident, the most common offenses on the roads are speeding; worn or defective tires; illegal or dangerous overtaking; not wearing a seatbelt; and driving while under the influence of alcohol. The main cause of these accidents is speeding, which represents 35\%. Cameroon has emphasized several reforms, notably the reform of transport documents, namely the driving license, the vehicle registration certificate and the secure vehicle inspection sticker. It should also be noted that road safety is governed by an abundance of regulations which include laws, decrees, orders and circulars, a collection of texts enforced in terms of road prevention and safety in Cameroon. In addition, there are among others laws, including: 
- law no. 96/07 of 8 April 1996 on the protection of the national road heritage; the law of 23 July 2001 governing the profession of road transport operator and road transport auxiliary;

- decree no. 79/341 of 3 September 1979 to regulate road traffic, modified and completed by decree no. $86 / 818$ of 30 June 1986;

- decree no. 99/724/PM of 29 September 1999 establishing the National Road Safety Committee, amended and supplemented by decree no. 2004/0606/PM of 17 March 2004;

- Order no. 009/MINT/DTT of 23 February 1998 regulating the transport of dangerous goods; and

- Order no. 010/A/MINT of 23 February 1998 regulating the homologation of vehicles and their equipment devices.

On another level, it is proven that all traffic accidents are the result of a malfunction of the "man-vehicle infrastructure" system. However, the analysis of road accidents shows that, of the three elements of the system, improving the skills and behavior of the human road user is the primary way to improve road safety. The perpetrators and victims of these accidents are road users-drivers, driving school promoters, technical inspection centers, transport company promoters, roadside inspectors, vehicle passengers and particularly vulnerable users such as pedestrians, children, young pupils, motorcyclists, cyclists, roadside residents, the elderly and the disabled.

For these users, awareness-raising and training in road safety rules must be carried out on a permanent and continuous basis so that safe behavior is adopted in order to live better with the road. Various means of training, education, information and awareness-raising are used, including outreach campaigns, media campaigns (television, radio and telephone), the press and posters. Public action in the field of road safety therefore emphasizes communication and awarenessraising, which are the main means of interaction between the public authorities and road users. Road safety measures frequently seek to encourage individuals to adopt responsible behavior to ensure road safety. Therefore an intervention strategy that is fundamentally characterized by the search for beneficial effects for the population. It is therefore an intervention strategy that is fundamentally characterized by the search for beneficial effects for the population (Baril) [15].

\section{Road Safety in the Cameroonian Press}

We studied the road safety thematic in three daily newspapers, namely: "Cameroon tribune", "Mutations" and "Le Messager". We collected sixty articles on the subject and carried out a content analysis which enabled us to identify the major trends. Generally speaking, on average, $60 \%$ of the articles published have headlines in black or red when it comes to serious accidents causing human losses: 19\% for "Cameroon tribune", 42\% for "Le Messager" 39\% for “Mutations". For less serious accidents, medium or small headlines in black and bold are generally used. Several articles (45\%) cover current events and contain no analysis, com- 
mentary or motive; they are content to describe the accident in a summary manner, without explanation, while nearly $40 \%$ of the articles, particularly those published by the private dailies "Le Messager" and "Mutations", point to the responsibility of the State. The police force in urban areas and the gendarmerie force in rural areas, sometimes referred to as "forces of law and order", are the main sources of information (65\%). In less than $5 \%$ of the articles, the source was unknown or reference was simply made to the testimonies of roadside residents or victims.

\section{Road Safety in the National Daily "Cameroon Tribune"}

In the daily newspaper "Cameroon Tribune", the road safety thematic is associated with several sub-thematic including: road safety campaigns, actions of the gendarmerie force on major roads, measures taken by the government, government assistance to victims of road accidents, recklessness of road users and the phenomenon of overloading among others. The wearing of seat belts and drinking and driving are also aspects that the national daily newspaper emphasizes. Particular emphasis is placed on the deployment of road safety campaigns on the main roads considered to be the most accident-prone, with, as a bonus, the publication of interviews given to the gendarmerie officials in charge of the said campaigns. These interventions of the gendarmerie force, presented as a "force of law and order", appear in the national daily newspaper in a constant manner with an increase in the Friday and Monday editions, to announce or report on the actions of this institution. The study of framing in the analysis of texts published by the national daily "Cameroon tribune" enabled us to identify the argumentative aim of the newspaper. Media news discourses made extensive use of the argumentative dimension of different types of framing. It can be a question of framing the debate around a thematic either by thematization or by questioning; and appreciated in a certain way by classifying it in a designative category; of interpreting a statement as an attitude that is supposed to be equivalent, as in the case of reported speech (Charaudeau) [16].

Motorists caution, drunk driving, overloading and seatbelt use are thus presented as the issues of greatest concern by the Cameroon Tribune. The newspaper is much more interested in the causes of traffic accidents and points out that despite the efforts of the gendarmerie force, motorists remain reckless. In a January 2018 edition, Cameroon Tribune stresses that on major roads, campaigns are intensifying and that the control-repression system is reducing the number of traffic accidents. The newspaper highlights the drop in the number of deaths between 2017 and 2019, and praises the initiatives of the Ministry of Transport. We can see that, in addition to informing its readers, the newspaper highlights all the governmental actions carried out in order to fight against road insecurity. We noticed that verbs such as: to accuse, to reject, to censure, to promise, to condemn, to want, to denounce, to deny, to wish, to think, to contest, to demand, are the verbs of attitude most often found in the articles published in Cameroon tri- 
bune. Most of them correspond to the subjective verbs analysed by KerbratOrecchioni [17], who points out that "these verbs pose more complicated problems for analysis than nouns and adjectives, whose possible evaluative value is very generally assumed by the speaking subject". At the same time, they correspond to the stated objectives of awareness-raising campaigns that emphasize control, awareness and repression.

\section{Road Safety in the Private Daily Newspaper "Le Messager"}

As far as the newspaper Le Messager is concerned, throughout our study period, the following themes were the subject of articles: the state of the roads (5\%), the issuing of permits. The most recurrent theme is the poor state of the roads, with an emphasis on the lack of road signs and signals and outdated road equipment, while themes relating to the state of vehicles and tiredness are more common. The most recurrent theme is the poor state of the roads, with an emphasis on the absence of signs and the dilapidated state of the road equipment, while issues related to the state of the vehicles and fatigue are the least discussed in Le Messager. In an article published in March 2019, a road user interviewed stated that:

"Provisions must be made for the roads to be safer. They need to be marked. They need to be lighted. What the taxpayer pays for the road should definitely be used for that. It's easy to sit in offices and say that we must ban this, we must do that. But when these ministers, these senior figures, have to travel, they travel in the latest model $4 \times 4$." (Le Messager) [18]

If the newspaper also mentions human causes such as incivility, fatigue and night travel, it specifies that road insecurity is the result of the administrations involved in the construction and operation of roads. Moreover, the newspaper mentions the problem of corruption as a cause of road accidents, referring to the state of vehicles, overloading and the existence of transport agencies that operate illegally. Concerning the responsibility of the administration, Le Messager addressed it from two angles: the state of the roads and the lack of road equipment on the one hand, and the lack of rigor regarding sanctions, the issuing of driving licenses and corruption in general on the other. Through its articles on road safety, or rather, road insecurity, Le Messager tries to draw the attention of its readers to the consequences of some of the scourges it has identified and related to the governance of the transport sector. The daily particularly denounces the administrations involved in the construction and operation of roads. According to L.M, in Cameroon, the fight against road insecurity requires first and foremost the actions of the state authorities which must be directed towards redefining the governance of the transport sector. The daily also maintains that the human causes of road accidents are justified by laxity and corruption. The newspaper states that the recurrence of serious accidents between Yaounde, Bafoussam and Douala makes users say that the three national roads that connect these cities constitute a "triangle of death". The verbs of attitude most used in the articles in Le Messager are: lose, wonder, question, attack, destroy, condemn and 
contest, with a respective percentage of $6.60 \% ; 6.37 \%$; $4.78 \%$; $5.69 \%$; $5.23 \%$; and $5.01 \%$. These verbs represent an opinion of the subject informing on the action, of a social actor (contestation, concern, etc.).

\section{Road Safety in the Private Daily Newspaper "Mutations"}

The private daily newspaper "Mutations" also reports on road safety issues. While it praises the action of the law enforcement agencies on the main roads, it highlights the numerous causes of road deaths, which call for the public authorities to be involved. Based on surveys and data collected in the field, the paper highlights certain aspects related to road safety. It mentions, for example, that several groups of people present high risks: these include truck drivers (on long distances such as Douala-Maroua) and bus drivers (in the case of inter-city transport) or even motorbike transporters, locally called benskin men who work almost 24 hours a day. The newspaper also mentions the use of the telephone, which is one of the new risks created by technology. This evolution favours the use of social networks within the population and one observes the use of the telephone on board the vehicle (at the wheel), on two-wheelers and tricycles, on the pavement (in the case of pedestrians) without any concern. Mutations also note that the Highway Code has been forgotten in the environment of road users in Cameroon. Driving is sometimes done without a license in full view of the law enforcement agencies, even though it notes that the Ministry of Transport is putting special emphasis on the control of the driving school sector in Cameroon, especially with regard to the development of training manuals and guides. In an article devoted to the training of motorists, the newspaper mentioned that Cameroon has more than 433 approved driving schools. It also raises the problem of the state of vehicles, stating that several vehicles are driving with worn tires, without headlamps or braking system. These facts are very often noted by the national gendarmerie force during roadside checks. This situation could be justified by the fact that, in a strategic and economic approach, drivers lend their tyres, headlamps, etc. to third parties to carry out the technical inspection, and afterwards the vehicles are returned to their initial state. For others, on the other hand, the technical inspection is obtained by telephone without the risk of having to worry about completing the police formalities at the inspection. In this case, Mutations joins the private daily Le Messager. The newspaper focuses on the big cities and reveals that in Douala and Yaounde, for example, overloading is observed on motorbikes as well as in taxis and transport buses. This deviant behavior is not without risk, especially in the event of an accident. A motorbike intended for two people is allocated to a whole family or group of people (three to four on average). As for the car, an inter-city bus with 70 seats on our roads carries about 100 people. In the event of an accident, the losses are considerable and cost both the families affected and the state a great deal. The daily leans more towards shared responsibility, pointing out that all road accidents occur in a context where awareness campaigns, strategies and appeals to fight against 
road accidents are being implemented either by the government or by civil society organizations.

At the end of our analysis, we noted that road safety information, as processed and disseminated by the selected daily newspapers, appears to be first-rate information. Three factors determine the quality of the treatment of journalistic information related to road accidents: the diversity of the subjects treated, the relay of the information and the quality of the analyses and more so with regard to the responsibilities of third parties. Road safety and traffic information also goes beyond the simple account of the tragedies caused by road accidents, which still occupies a very important part of road safety information. Similarly, the pre-eminence of the discourse on the individualisation of the causes of road accidents is also partly explained by the economic and political logic of presenting a simple problem (Grossetête) [19]. It should be noted, however, that the media coverage of road risk is less and less based on an issue that considers accidents as a "fatality" or an unfortunate "chance". Although road risk is still presented in certain news items that emphasize the spectacular nature of accidents, this perception is far from being dominant. Admittedly, daily newspapers still carry the headline "The road kills", but they dwell more on the causes and consequences. The dominant perception of the causes of road accidents tends to focus not on an imaginary fate but on the individual and sometimes "delinquent" behavior of drivers on the one hand and the responsibility of the State on the other. In the way they cover the issue of road safety in the media, newspapers stigmatized a category of motorists. A list of deviant behaviors such as drunk driving, driving without a license or with a dubious license, etc. can be listed. However, while the newspapers strongly emphasized individual responsibility, the solutions proposed to remedy such behaviour may vary. For the newspaper Le Messager, it is necessary to insist on the action of the administrations and the role of the State. The three newspapers studied recognize the relevance of financial sanctions and advocate for judicial ones. Hence the tendency to relay the actions undertaken by the national gendarmerie force in this direction. This position is opposed to the media trend that questions the State's road safety policy. Other solutions proposed in the press concern a reform of driver training, as this is considered ineffective.

\section{Communication, Awareness, Road Prevention and the Importance of Social Marketing}

Road accidents are among the most important public health problems in Cameroon. While road conditions and other factors can be mentioned, the behavior of road users and road prevention measures remain important. We focused on users of the Yaoundé-Douala and Douala-Bafoussam roads to conduct our study on the effectiveness of road safety awareness campaigns. A first exploratory study on this road axis carried out with twenty (20) users of this road, allowed us to note that the latter had convergent points of view on human and environ- 
mental factors, notably: speeding, alcohol, the state of vehicles, overloading, night travel and the state of the road, among others. Subsequently, we conducted semi-directive interviews with fifty (50) users of national roads $n^{\circ} 3$ and $n^{\circ} 5$ interviewed in interurban transport agencies and at roadside checkpoints. We found that those who agreed to be interviewed were predominantly male with a percentage of $85 \%$ against $15 \%$ for women. In addition, our sample was composed mainly of users with a secondary level of education and no schooling, which allows us to conclude that in the Cameroonian environment, we find more users with a secondary level of education.

\section{Road Safety and Communication Strategy}

It should be noted from the outset that communication is used in the fight against road insecurity at several levels, whether it be awareness campaigns or social campaigns focusing on threats (such as control, surveillance and repression). Campaign strategies based on shock are almost non-existent in road safety in Cameroon. However, there are signs on the roads reminding us of the number of deaths at various spots. These are in fact black figurines, accompanied by signs specifying the number of people who died following an accident at a specific spot. Along the Douala-Nkongsamba road, for example, there are several such signs. These signs not only inform about the accidents that have occurred at these spots, but also aim to instill fear in users and consequently change their behavior on the road. Thus, when they arrive at these locations and observe these signs, the first idea is to reduce speed and improve driving behavior. Of those who responded to our interviews, $89 \%$ said that road safety is the result of the behavior of road users, compared to $11 \%$ who said that road safety is the result of other factors such as the state, the poor state of the roads, the environment, etc. Among the causes of accidents are excessive speed, alcohol/drug consumption, poor road conditions, the use of mobile phones while driving and other causes such as distraction, wheel bursts, bad weather, etc. We can classify them into three groups: the first related to man, the second to the vehicle and the third to the environment as presented by Charbit [20]: "in the field of road safety, we traditionally refer to the triangle Man-Vehicle-Environment".

On the whole, we noted that communication campaigns are not formally implemented, users are made aware during road safety campaigns and certain messages are conveyed through signs along the roads. One might therefore rightly think that communication on road safety is carried out on the roads by means of communication that arouses fear through signs. Therefore, the question that is asked is: Does fear communication therefore have a positive influence on the responsible behavior of road users? Witte [21] defines fear communication as an emotion that is evaluated negatively, but which can be accompanied by a high rate of alertness to reflection. The opinion collected from road users gave us a clear picture. The road users interviewed stated that the gendarmerie officials in charge of the awareness units on the roads have developed a more structured 
and organized communication, which emphasizes awareness. Although they adjust their behavior on the road according to the presence of speed cameras and, above all, in order to avoid financial penalties, the users recognize that the presence of the gendarmerie force brings more discipline to the roads. It also appears that roadside checks are one of the road prevention measures that the government and police forces uses to regulate the uncivil behavior of road users. Fixed and mobile radars have also been set up to flashed motorists who have violated the Highway Code; roadside checkpoints to monitor and punish offences with fines or impoundment, depending on the case.

Regarding the signs indicating the number of deaths, users say that they are a warning to motorists to slow down each time, but that once they have crossed the area, their usual behavior resumes. It should also be pointed out that the users interviewed who had already been involved in accidents explained their accident exclusively by external factors. In this case, they primarily emphasized the behavior of other drivers and secondarily the environment (road conditions, bad weather), the vehicle or the behavior of pedestrians to explain their accident. Nowhere does a causal explanation appear in which a driver mentions a cause related to his own behavior to explain his accident.

Clearly, it appears that road users are sensitive to any manifestation of fear, repression or punishment. In awareness-raising strategies, communication through fear could well contribute to bringing road users to greater discipline, all the more so as the study of the impact of emotions in prevention campaigns such as road safety is part of the affective research trend that has emerged since the early 1980s. Dupuis [22] shows that fear belong to the emotions and more particularly to the three primary emotions of anger, love and hate. It arises from the awareness of a threat that could eventually occur (such as accidents) and put the individual in danger (death or lifelong disability). This can have an impact not only on his life because he can no longer work even if he is alive, but also for those around him who have to take care of him and even for the society as a whole.

In summary, it is not only the presence of controls on the public highway that leads users to respect the Highway Code. Moreover, they do not respect this code because there is radar, but rather because they are afraid of being stopped. To this end, it would undoubtedly be essential for road safety actors to develop road prevention measures by integrating fear and repression (questioning), as road users in Cameroon are sensitive to this. The users also recognize that apart from the gendarmerie force, other actors intervene in awareness raising, such as non-governmental organizations which take several measures, including social marketing through communication and awareness raising.

In the field of road safety, several tools can be used to change the behavior of road users, ranging from awareness campaigns and social advertising to the integration of the road safety component into teaching programs and training in driving schools. We noted that the effectiveness of fear communication and roadside enforcement is dependent on two conditions. The first is the importance 
given by the target citizens to the benefits of adopting the prescribed behavior mentioned in the communication, and the second is the magnitude of the estimated efforts to achieve the recommended behavioral changes, since if the perception of the efforts to be made outweighs the expected benefits for the users. This perception is also influenced by the social environment itself, as the social environment as a whole is favorable to change, and each individual will be open to it.

\section{Social Advertising and Road Safety}

It should be pointed out, however, that for social advertising or a prevention campaign to really achieve its objectives, it must be built around three types of arguments, as presented by Cossette and Daignault [23]: rational elements (facts, figures, etc.), which seem to be the most important; affective elements (humor, fear, shock, etc.), which are used extensively by advertisers; and non-verbal elements (kinesics, humor, etc.), which are used extensively by the media.), which seem to be the most important; affective elements (humor, fear, shock, etc.), which are used extensively by advertisers; and non-verbal elements (kinesics, colors, typography, etc.), which are often treated at a sub-attentional level and which act in close connection with the affective elements. On major roads such as Douala-Yaoundé, Douala-Bafoussam or Bafoussam-Yaoundé, known as the triangle of death, driving is done outside the law. No respect for the Highway Code, overloading, dangerous overtaking, bad crossings, categorical refusal to wear seatbelts, absence of technical inspections; the list is far from exhaustive. These much decried behaviors have not yet found solutions. However, the State has the coercive means to regulate this behavior in order to restore road safety. In the case of alcohol levels alone, we found that most of the users interviewed were completely unaware of the permitted level and vaguely stated that they should not consume alcohol before driving. For users of major roads, the campaigns of the national gendarmerie force conducted by numerous teams have led motorists to change their behavior. On the main roads, almost all crossings are the subject of information either by headlights or by hand signals to know how to regulate one's speed and behavior (seat belts, overloads, alcohol) according to the presence or absence of controls and radars on the said roads.

These behavioral regulation tools based on solidarity between motorists have begun to bear fruit but are not enough. Social marketing is first and foremost a tool for convincing the population to adopt an idea or a behavior. However, we must be aware that awareness raising does not allow us to exceed a certain threshold of compliance with the message advocated and that it is the combined effect of awareness raising, legislation and coercion that gives promising results (wearing a seat belt or reducing speed, for example) (Brault and Letendre) [24]. We therefore agree that it is essential to strengthen the system for combating road insecurity with more communication and, more specifically, social marketing, with the aim of achieving changes in the behavior of road users. 


\section{Conclusion}

The consequences caused by road accidents constitute a major problem for society, the economy, development and public health in Cameroon. The problem of road safety is therefore a major issue. We therefore questioned the representations of road safety in the press and wondered about the way in which users are made aware of the problem, in relation to the effectiveness of the strategies deployed. While we noted that speeding, driver recklessness, dangerous overtaking and lack of control are some of the critical causes of road accidents in Cameroon, we also found that the lack of awareness of road safety issues is a major cause of road accidents. In order to bring drivers to change these behaviors, repression alone is not enough; it must be dissuasive and not exclusively repressive. If we recognize that acting in the media in matters of traffic and road safety is to highlight a problem at the heart of the solutions sought by the State, it must be admitted that sensitization through the media is not enough on its own. It is therefore important to include social marketing as a major element that can combine the best elements of traditional behavioral change approaches into an integrated framework of planning and action, using techniques such as fear communication. Therefore, in order to make road safety measures effective, we suggest that, in addition to roadside campaigns, lessons related to road safety education and compliance with traffic laws should be introduced into school curricula and the targets of road safety campaigns should be extended to facilitate behavior change. The road prevention approach can therefore be modeled on the social marketing approach, which is also similar to that of commercial marketing in that it is based on a systematic approach based on prior diagnoses (such as the incivility of public road users). This approach would consist of segmenting the targets well; targeting the segment in which it is possible to achieve results more easily and quickly; determining the desired behavior; developing a good understanding of the expectations, representations and barriers to this behavior; developing communication campaigns using the tools of mix marketing; and monitoring and evaluating the results through changes in behavior.

\section{Conflicts of Interest}

The author declares no conflicts of interest regarding the publication of this paper.

\section{References}

[1] Muhlrad, N. (2009) Road Safety Management Systems. A Comprehensive Diagnosis Method Adaptable to Low and Middle incoMe Countries. Synthèse INRETS $\mathrm{n}^{\circ}$ 59, $154 \mathrm{p}$.

[2] Ngueutsa, R. (2012) Croyances et comportements de sécurité des usagers et agents du trafic routier: une étude des perceptions et de l'explication naïve des accidents de la route au Cameroun. Thèse de Doctorat en Psychologie sociale et expérimentale, Université de Grenoble, France, 412.

[3] Djiepmo, N. and Guy, R. (2008) The Challenges of Road Safety in Urban Areas in 
Cameroon: The Case of Motorbike Taxis in Yaoundé. Mémoire de Master Economie des Transports et Logistique des Échanges, Université de Yaoundé, Yaoundé, 84.

[4] Hadji, M.A. (2018) Effectiveness of Road Prevention Measures on the Behaviour of Road Users in Cameroon. Mémoire, Ecole Normale Supérieure d'Enseignement Technique de l’Université de Douala, Douala, 86.

[5] Misse, M. (2006) La Communication stratégique: De l'appui au "développement" à la promotion du "Changement Social": Une Communication de Connivence? Contribution au Colloque International Réuni à Douala en Avril, Douala, 2006.

[6] Lerner, D. (1958) The Passing of Traditional Society; Modernizing the Middle East. The Free Press, Illinois, 240.

[7] Bernier, S. and Dumont, D. (1993). Perception des habiletés de conduite, évaluation du risque d'accident et attitudes face aux comportements de conduite risqué. Institut National de Santé Publique du Québec, Montréal (Québec), 96 p.

[8] Shinar, D. (1978) Psychology on the Road: The Human Factor in Traffic Safety. John Wiley and Sons, New York, 1095.

[9] Higelé, P. et Hernja, G. (2008) La compréhension des situations de conduite et les prises de de risques chez les conducteurs novices jeunes. Recherche Transport Sécurité, 98, 13-37. https://doi.org/10.3166/rts.98.13-37

[10] Andreasen, A.R. (1994) Social Marketing: Its Definition and Domain. Journal of Public Policy and Marketing, 13, 108-114. https://doi.org/10.1177/074391569401300109

[11] Kotler, P. and Roberto, E. (1989) Social Marketing: Strategies for Changing Public Behavior. Free Press, New York, 401.

[12] Berelson, B. (2000) Content Analysis in Communication Research, New York, Hafner Publ., 1971, p. 18. (Cité par Jean de Bonville, L'analyse de contenu des médias, Bruxelles, De Boeck, p. 9, 451.)

[13] Nga Ndongo, V. (1993) Les médias au Cameroun: Mythes et délires d'une société en crise. L'Harmattan, Paris, 288.

[14] Guebediang, S. (2017) Le gouvernement au front. Cameroon Tribune, N¹1426/7625, 10-11.

[15] Baril, G. (2016) L'efficacité du marketing social en promotion des saines habitudes de vie. Institut National de Santé Publique du Québec, Québec, 79.

[16] Chareaudeau, P. (1995) Le dialogue dans un modèle de discours. Cahiers de Linguistique Française, 17, 141-178.

[17] Kerbrat-Orecchioni, C. (1980) L’Énonciation-De la subjectivité dans le langage. Armand Colin, Paris, 290.

[18] Tchapmi, C. (2019) Ce que pensent les usagers de la route. Le Messager, 6.

[19] Grossetête, M. (2008) L'Etat conducteur. La circulation de la sécurité routière dans les journaux télévisés français. In Dominique, M., Ed., Communication et Médiatisation de L'etat. La Politique Invisible, Presses Universitaires de Grenoble, Grenoble, 23-52.

[20] Charbit, C. (1997) Les facteurs humains dans les accidents de circulation: Un potentiel important pour des actions de prevention. MAIF Fondation, Paris, 126.

[21] Witte, K. (1992) Putting the Fear Back into Fear Appeals: The Extended Parallel Process Model. Communication Monographs, 59, 329-349.

https://doi.org/10.1080/03637759209376276.

[22] Dupuis, A. (2011) Faire jaser pour faire agir... La réception des publicités sociales 
chocs de sécurité routière par les Web acteurs, Mémoire de Master, Université du Québec à Trois-Rivières, Trois-Rivières, 98.

[23] Cossette, C. and Daignault, P. (2011) La publicité sociale: définitions, particularités, usages. Télémaque, Québec, 385.

[24] Brault, M. and Letendre, P. (2002) Opérations Pieds Pesants, présentation au 37ème congrès de I'Association Québécoise des Transports et des Routes. 